\title{
PREVENTION OF NON-COMMUNICABLE DISEASES UNDER THE COVID-19 PANDEMIC
}

\author{
Yelizarova O.T., Hozak S.V., Polka N.S., Parats A.M., Stankevych T.V.
}

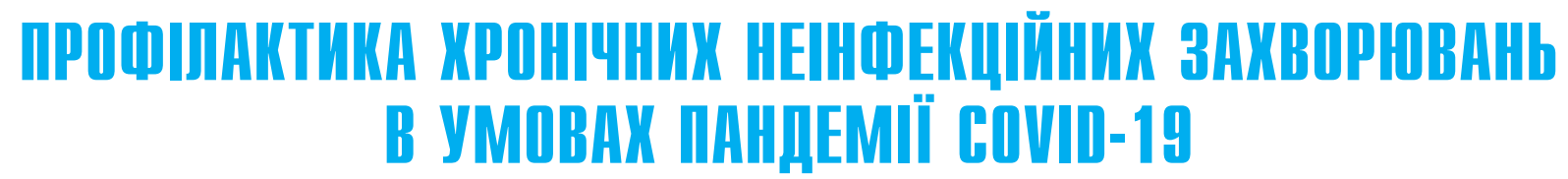

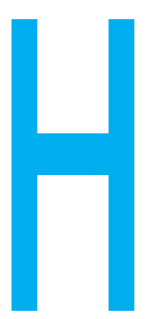

ЄЛІЗАРОВА О.Т., ГОЗАК С.В. ПОЛЬКА Н.С., ПАРАЦ А.М., СТАНКЕВИЧ Т.В.

ДУ «Інститут громадського здоров'я ім. О.М. Марзєєва

НАМН України», м. Київ адзвичайне напруження всіх ресурсів галузі охорони здоров'я у зв'язку з пандемією COVID-19 стало новим викликом перед профілактичною медициною щодо пошуку нових шляхів покращання допомоги населенню і вдосконалення існуючих. За даними ВОО3, обмеження медичних ресурсів під час пандемії призвело до зниження якості надання медичної допомоги населенню з хронічними неінфекційними захворюваннями (у тому числі онкохворим) відміни або зниженню охоплення населення скринінговими програмами та інших важливих заходів, що сприяють підтримці здоров'я населення [1].

Хронічні неінфекційні захворювання (НІ3) є причиною майже $70 \%$ смертей населення у світі і 91\% - в Україні [2]. Найбільший внесок обумовили серцевосудинні, онкологічні, захворювання дихальних шляхів та діабет [2-3]. Нині актуальність профілактики НІЗ набуває особливого значення, адже хворі на ці захворювання є групою ризику з тяжким перебігом COVID-19 [4-5].
ПРОФІЛАКТИКА ХРОНІЧНИХ НЕІНФЕКЦІЙНИХ ЗАХВОРЮВАНЬ В УМОВАХ ПАНДЕМІЇ COVID-19

Єлізарова О.Т., Гозак С.В., Полька Н.С., Парац А.М., Станкевич Т.В.

ДУ «/нститут громадського здоров'я ім. О.М. Марзєєва НАМН України», м. Київ

Зростання поширеності хронічних неінфекційних захворювань (НІЗ), які зумовлюють високий рівень смертності та інвалідизації населення, викликає необхідність досліджень у напрямку їх профілактики та вдосконалення шляхів ранньої діагностики. У нинішніх умовах актуальність профілактики НІЗ набуває особливого значення, адже хворі на ці захворювання є групою ризику з тяжким перебігом COVID-19. 3 урахуванням процесів урбанізації дослідження особливостей епідеміології факторів ризику розвитку НІЗ необхідно проводити для міського $i$ сільського населення окремо.

Метою дослідження є систематизація факторів ризику розвитку неінфекційних хронічних захворювань міських жителів України.

Матеріали і методи дослідження.

Використовували методи структурно-логічного аналізу, бібліосемантичний.

Проведено контекстний пошук у таких базах даних, як Державна служба статистики України, the World Health Data Platform, the Global Burden of Disease IHME, a також y доступних публікаціях у системі PubMed, CochraneLibrary.

Результати. Демографічні тенденції в Україні характеризуються переважанням смертності над народжуваністю. Від 1990 року населення скоротилося на 19,2\%. НІ3 $\epsilon$ основною причиною смертності українців. Фактори ризику, що сприяють розвитку НІЗ $\epsilon$ поширеними у популяції. Зростання смертності зумовлене дією чинників ризику, пізньою діагностикою НІЗ. Надмірну масу тіла та ожиріння має більшість населення віком понад 18 років, а у великих містах за останні 5 років спостерігається різке збільшення частки осіб з ожирінням. Гіподинамія та нераціональне харчування є характерними рисами міських жителів. Додатковим чинником ризику розвитку НІЗ $є$ забруднення атмосферного повітря.

Висновки. Для міського населення України характерними є такі чинники ризику НІЗ, як старіння населення, гіпокінезія, нераціональне харчування, забруднення атмосферного повітря, гіподіагностика НІЗ. Всі ці фактори у поєднанні з низьким соціальноекономічним рівнем більшості населення країни формують необхідність активнішого впровадження профілактичних заходів.

Ключові слова: фактори ризику, хронічні неінфекційні захворювання, забруднення атмосферного повітря, смертність, COVID-19. 
Визначено, що до провідних факторів ризику, які сприяють розвитку НІ3, належать нездорове харчування, тютюнопаління, надмірне споживання алкоголю, недостатня фізична активність [6]. Додатковим фактором ризику $є$ стрімка урбанізація, результатом чого $€$ забруднення повітря, нераціональна забудова, знищення зелених насаджень, щільні інформаційні потоки, шум та велика кількість відходів, які негативно впливають на здоров'я населення, а пандемія COVID-19 поглиблює ці проблеми. Україна належить до країн 3 середнім рівнем урбанізації. Кількість населення міст становить близько 70\%, тобто під впливом цих факторів ризику перебувають понад 29 мільйонів людей.

Згідно з усталеною думкою перевагою проживання у містах $€$ більший доступ до висококваліфікованої медичної допомоги, ніж у жителів сільської місцевості. Втім у містах сильніше виражена розбіжність серед різних верств населення щодо доступу до сфери послуг, у тому числі медичних, дорожча вартість життя і вищий ризик розвитку неінфекційних хронічних та інших захворювань [7].

Отже, вищенаведене актуалізує важливість профілактики НІЗ для міського населення України в умовах пандемії COVID-19.

Метою дослідження $\epsilon$ систематизація факторів ризику розвитку неінфекційних хронічних захворювань міських жителів України та розробка напрямків їх профілактики.

Матеріали і методи дослідження. Використовували методи структурно-логічного аналізу, бібліосемантичний. Проаналізовано демографічні, поведінкові та екологічні фактори, що впливають на стан здоров'я населення України, за допомогою баз даних з відкритим доступом: Державної служби статистики України (ukrstat.gov.ua), Міністерства

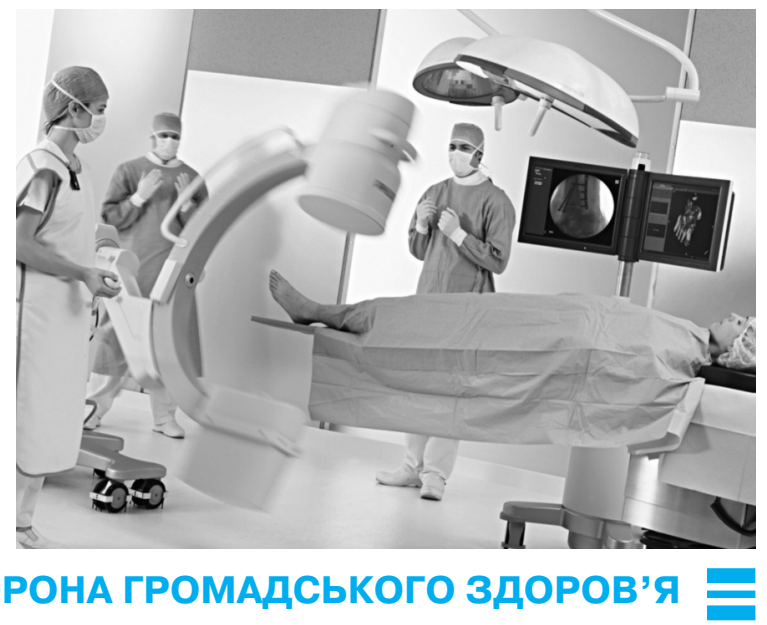

охорони здоров'я України ( https://moz.gov.ua/), Міністерства захисту довкілля та природних ресурсів України (https://mepr.gov.ua/), вебпорталу Верховної Ради України (https://www.rada.gov.ua/), the World Health Data Platform (https://www.who.int/data), the Global Burden of Disease of the Institute for Health Metrics and Evaluation (http://www.healthdata.org/), а також доступних публікацій у системі PubMed, Cochrane Library.

Результати. За даними Державної служби статисти-

ки України, на 1 лютого 2021 року в Україні проживало 41554836 осіб (табл. 1), з них близько 30\% осіб віком понад 65 років у містах і сільській місцевості. Порівняно з 2020 роком у 2021 році встановлено скорочення населення на 314062 осіб, а з 1990 року населення скоротилося на 19,2\%. За прогностичними розрахунками the Global Burden of Disease [8], у разі збереження нинішніх тенденцій у 2100 році чисельність української популяції становитиме 17,5 мільйонів з пере-

Таблиця 1

Демографічна характеристика населення великих міст України *

\begin{tabular}{|c|c|}
\hline Показник & $\begin{array}{c}\text { Січень - грудень } \\
2020\end{array}$ \\
\hline $\begin{array}{l}\text { Чисельність наявного населення (за оцінкою) } \\
\text { на } 1 \text { лютого } 2021 \text { року }\end{array}$ & 41554836 \\
\hline $\begin{array}{l}\text { Середня чисельність наявного населення } \\
\text { у січні-грудні } 2020 \text { року }\end{array}$ & 41745385 \\
\hline $\begin{array}{l}\text { Чисельність постійного населення (за оцінкою) } \\
\text { на } 1 \text { січня } 2021 \text { року }\end{array}$ & 41418717 \\
\hline $\begin{array}{l}\text { Середня чисельність постійного населення } \\
\text { у січні-грудні } 2020 \text { року }\end{array}$ & 41575748 \\
\hline Середня тривалість життя чоловіків & 66,9 \\
\hline Середня тривалість життя жінок & 76,9 \\
\hline Загальний приріст, скорочення (-) населення & -314062 \\
\hline Природний приріст, скорочення (-) населення & -35790 \\
\hline Кількість живонароджених & 21931 \\
\hline Кількість померлих & 57721 \\
\hline Міграційний приріст, скорочення (-) населення & 9316 \\
\hline Кількість великих міст ${ }^{\star \star}$ & 459 \\
\hline Кількість малих міст** & 882 \\
\hline Кількість сільських населених пунктів *夫 & 28372 \\
\hline Відсоток міського населення & 67,7 \\
\hline Великі міста & 39,6 \\
\hline Малі міста & 28,1 \\
\hline
\end{tabular}

Примітки: * - за даними Державної служби статистики України ( http://www.ukrstat.gov.ua/);

** - за даними веб-порталу Верховної Ради України (https://bit.ly/31uPC9O).

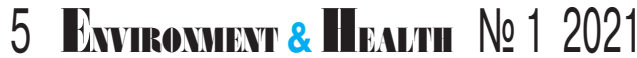


важанням частки населення старшого віку (рис. 1).

Загальний коефіцієнт народжуваності в Україні 1990 року становив 1,7, 2017 1,4. Згідно з прогностичними розрахунками the Global Burden of Disease [8] він надалі знижуватиметься і в інших країнах (рис. 2). Але порівняно зі східно-європейськими країнами коефіцієнт народжуваності в Україні найнижчий.

У структурі захворюваності українців, за даними Держкомстату, домінують хвороби органів дихання, а у структурі смертності - серцевосудинні хвороби. 2020 року українці помирали від таких хвороб (в абсолютних цифрах): ішемічна хвороба серця - 284997 осіб, цереброваскулярні хвороби 78140 , злоякісні новоутворення - 77161, хвороби органів травлення - 24215, хвороби органів дихання 16705, ендокринні хвороби, розлади харчування та порушення обміну речовин 2333, COVID-19 - 20709. За допомогою впровадження заходів первинної та вторинної профілактики можна знизити розвиток серцевосудинних захворювань на 80\%, на 40-50\% - усіх випадків раку і досягти значущого зниження смертності, а також знизити ризик тяжкого перебігу COVID-19 [9-13]. Хоча програми з профілактики серцево-судинних захворювань у розвинених країнах показують позитивні результати, але поки що не спрацьовують з такими станами, як ожиріння і цукровий діабет, поширеність яких зростає у більшості країн світу, як і в Україні [14-15].

Відомо, що первинна профілактика полягає у попередженні розвитку захворювань, а вторинна профілактика базується на ранньому виявленні та контролі вже наявних захворювань з метою

Вікова структура населення для чоловіків та жінок у 1990, 2019 та 2100 роках. Прогнозовані дані на основі результатів Global Burden of Disease [8]
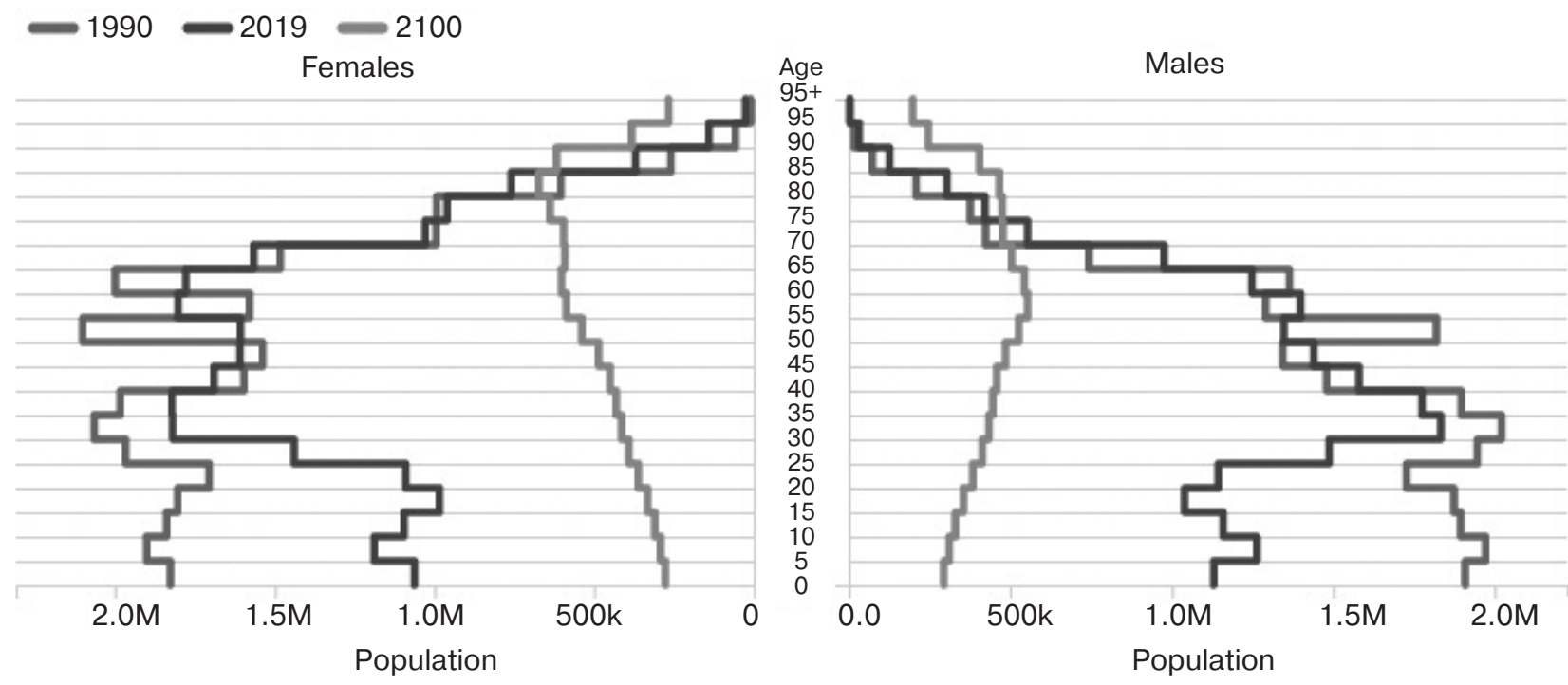

Рисунок 2

Загальний коефіцієнт народжуваності (середня кількість дітей, яких жінка виношує протягом життя), 1990-2100 рр. [8]

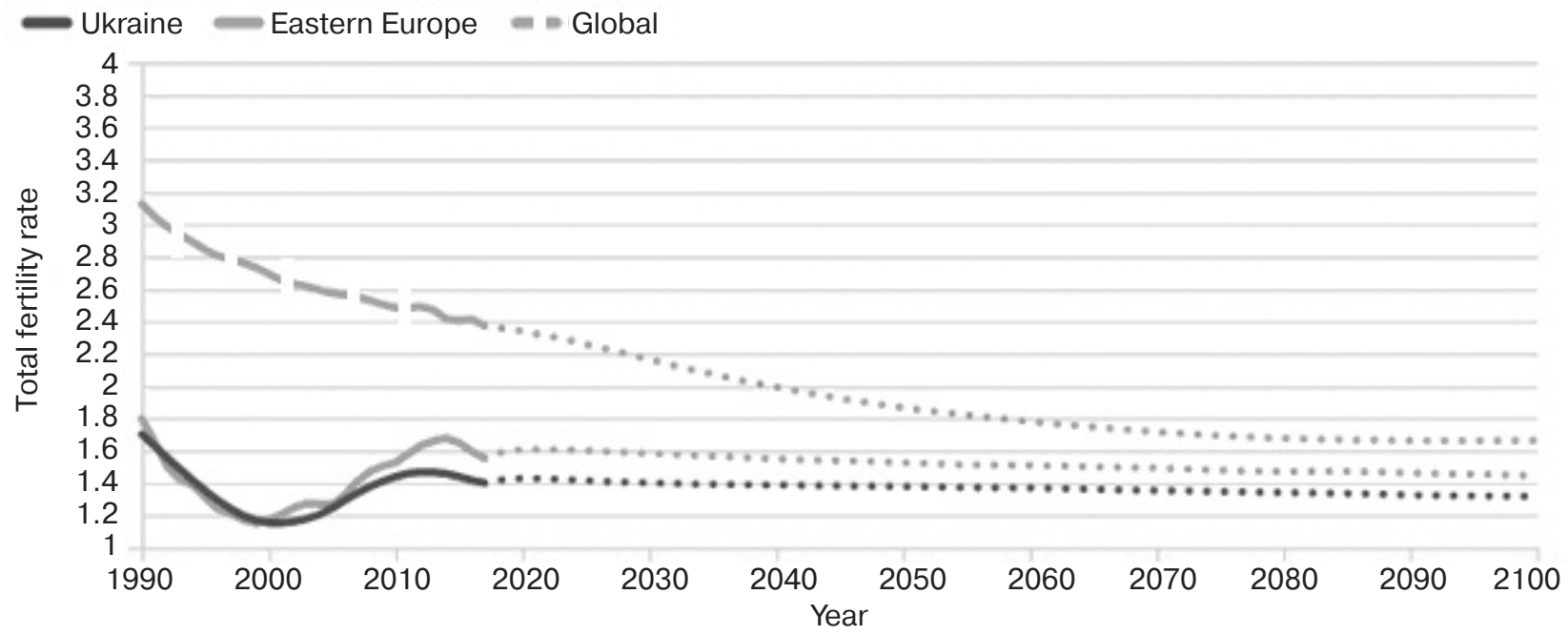

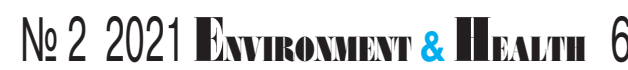


PREVENTION OF NON-COMMUNICABLE DISEASES UNDER THE COVID-19 PANDEMIC Yelizarova O.T., Hozak S. V., Polka N.S., Parats A.M., Stankevych T.V.

SI «O.M. Marzieiev Institute for Public Health, NAMS of Ukraine», Kyiv

\section{Background: The growing prevalence of} non-communicable diseases (NCD), which cause the high mortality and disability, necessitates the research to prevent them and improves early diagnosis. Currently, the relevance of the NCD prevention is of particular importance because the $N C D$ patients have an increased risk of the severe course of the COVID-19. Taking into account the processes of urbanization, the study of the features of epidemiology of risk factors for the development of the NCD should be conducted separately for urban and rural populations.

Objective: We aimed to systematize the risk factors of non-communicable diseases in the urban population of Ukraine.

Materials and methods: We used the bibliosemantic method and method of structural and logical analysis. A contextual search was conducted in such databases as the State Statistics Service of Ukraine, the World Health Data Platform, the IHME Global Burden of Disease, as well as in the available publica- tions in the system of PubMed, Cochrane Library.

Results: Demographic trends in Ukraine are characterized by a predominance of mortality over birth rate, and since 1990, the population has decreased by $19.2 \%$. Non-communicable diseases are the leading cause of death in the Ukrainians and risk factors that contribute to NCD are common in the population. The increase in mortality is due to both the effect of risk factors and the late diagnosis of the NCD. More than a half of the population aged over 18 years is overweight and obese. In large cities over the past 5 years there has been a sharp increase in the proportion of obese people. Hypodynamia and irrational nutrition are also characteristic features of urban residents. Atmospheric pollution is an additional NCD risk factor.

Conclusions: The urban population of Ukraine is characterized by such risk factors of the NCD as population aging, hypokinesia, irrational nutrition, atmospheric pollution, hypodiagnosis of the NCD. All these threats in the combination with a low socio-economic level of the population form a need in more active implementation of the preventive measures.

\section{Keywords: risk factors, non-communicable diseases, atmospheric pollution, mortality, COVID-19.}

.попередження переходу їх у більш тяжкі форми та розвитку ускладнень.

За даними [6], в Україні основними факторами ризику смертності та інвалідності за значимістю є високий артеріальний тиск, нераціональне харчування, куріння, дисліпідемія, надмірна вага та ожиріння, споживання алкоголю, високий рівень глюкози, забруднене атмосферне повітря, ниркова недостатність. Зауважимо, що метаболічне здоров'я тісно пов'язане 3 рівнем рухової активності [16]. Дослідження STEP показало, що в Україні 32,8\% населення має сполучення 3-5 таких основних факторів ризику, як куріння, недостатнє споживання овочів/фруктів, надмірне споживання солі, недостатня фізична активність, надмірна вага/ожиріння, підвищений артеріальний тиск [2].

Отже, основою профілактики захворювань є модифіка- ція способу життя, що означає достатню рухову активність, раціональне харчування, відсутність шкідливих звичок, сприятливе для здоров'я навколишнє середовище, впровадження скринінгових програм для виявлення захворювань на ранньому етапі та підвищення медичної освіти населення [11-17]. Втім, останні дослідження показують, що близько 70\% підлітків ведуть малорухливий спосіб життя, майже $15 \%$ палять та 22\% щодня вживають алкоголь [18-19]. За даними Держкомстату, курить кожна п'ята молода людина віком 18-29 років та близько $30 \%$ осіб старшого віку.

Дослідження рухової активності дітей та підлітків показало, що серед міських підлітків в Україні лише $45,4 \%$ хлопців та 21,4\% дівчат досягають рекомендованої тривалості рухової активності 60 хв./добу [19]. Але разом з тим сидячі заняття становлять більшу частку денної активності дітей понад 10 годин/добу. Низький рівень фізичної активності українських дітей та підлітків відзначено й в інших дослідженнях [20]. Зауважимо, що спортом в Україні мінімум раз на тиждень займаються 23,1\% жінок і $35,1 \%$ чоловіків віком понад 18 років. У великих містах ці цифри дещо більші і становлять відповідно $31,7 \%$ та $45,2 \%$. Але, за the World Health Data Platform, необхідних для підтримки здоров'я 150 хвилин помірного і/або 75 хвилин інтенсивного фізичного навантаження досягає лише кожен п'ятий (20,69\%, ДІ 15,08-27,67).

Малоактивний спосіб життя та нераціональне харчування призводять до того, що вже у підлітковому віці споживання калорій на 9,8\% у хлопців та на $13,1 \%$ у дівчат перевищує рекомендовані норми [19]. Збереження такого способу життя обумовлює зростання

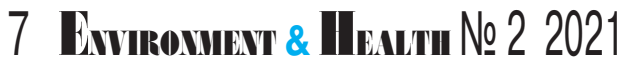


частки населення 3 надмірною вагою та ожирінням. За даними обстеження домогосподарств, у 2020 році частка населення віком понад 18 років, що мала IMT

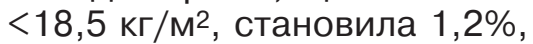

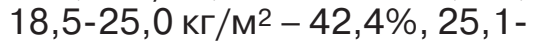

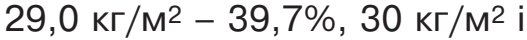
більше - 16,7\% [21]. Тобто загалом 56,4\% населення України мають надмірну вагу та ожиріння.

Частка дорослого населення з ожирінням за останні п'ять років збільшилася від 15,5\% у 2016 році до $16,7 \%$ у $2020\left(R^{2}=0,714\right)$. При цьому найбільші зрушення відзначено у жителів великих міст з відповідними значеннями - $16,8 \%$ та $17,7 \%$ $\left(R^{2}=0,873\right)$. Серед сільських жителів також встановлено збільшення частки населення 3 ожирінням $\left(R^{2}=0,721\right)$ від $16,8 \%$ до $17,1 \%$, а у малих містах показники залишаються стабільними зі значеннями близько 18,0\%. На рисунку 3 представлено виявлені тенденції. Не сприяє покращанню цієї ситуації агресивна реклама у ЗМІ щодо споживання нездорової їжі. Між тим роль ЗМІ у профілактиці НІЗ потенційно

\section{Частка населення віком понад 18 років зі значенням індексу маси тіла $>30$ кг/M², \% (за даними Держкомстату)}

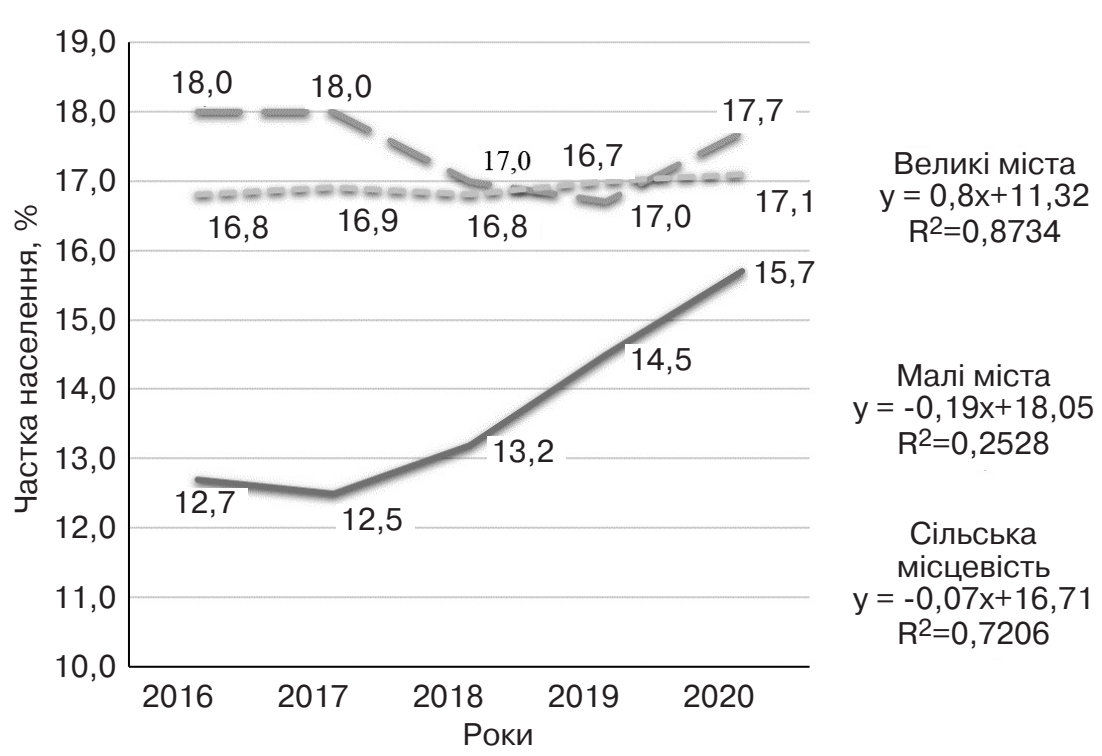

— Великі міста — Малі міста - -- Сільська місцевість

може бути значущою [22]. Ожиріння та малоактивний спосіб життя підвищують ризик розвитку серцевосудинних захворювань та діабету 3 незворотними метаболічними змінами. Також підвищений індекс маси тіла понад 25 кг/м² $€$ фактором ризику ускладнень при COVID-19 [23].

Підвищений ризик метаболічних порушень у населення України також збільшується внаслідок гіподіагностики переддіабету та діабету 2 типу. Між тим, за даними дослідження STEP, близько 7\% українців, тобто майже 3 млн. осіб мають рівень глюкози у крові натще понад 7 ммоль/л. Акцентуємо увагу на тому, що наявність діабету у пацієнта підвищує ризик тяжкого перебігу COVID-19 у 7,7 разів [24]. Ще одним фактором ризику смертності $€$ підвищений артеріальний тиск. Цей же фактор у 3,5 рази збільшує ризик смерті від COVID-19. У дослідженні STEP встановлено, що підвищений систолічний артеріальний тиск понад 140 мм рт. ст. і діастолічний понад 90 мм рт. ст. 2019 року мали 34,8\% населення України. У $33,6 \%$

Рисунок 3 підвищений тиск було виявлено під час проведення дослідження вперше у житті, 17,6\% мали призначене лікування з цього приводу, але не приймали ліки, 34,4\% приймали ліки, але мали неконтрольоване підвищення тиску, і лише 14,4\% приймали ліки і мали тиск нижчий, ніж 140/90 мм рт. ст. Тобто нині необхідним $є$ посилення обізнаності населення у цьому напрямку і вдосконалення управлінських рішень з розробки профілактичних заходів.

Ефективне впровадження профілактичних програм неможливе без поінформованості населення щодо факторів ризику та комплаєнсу. На жаль, обізнаність населення щодо факторів ризику розвитку НІЗ також досить низька. У дослідженні [25] продемонстровано, що лише $20 \%$ респондентів були обізнані щодо п'яти основних чинників ризику (підвищений артеріальний тиск, тютюнопаління, гіподинамія, ожиріння та надмірна вага, надмірне вживання алкоголю). У цьому ж дослідженні визначено, що тільки 25,3\% респондентів, які мають фактори ризику, отримували поради від сімейного лікаря щодо їх корекції. Дослідження STEP [2] показало, що лише третина 3 $23,4 \%$ населення України віком 40-69 років з високим ризиком розвитку такої патології, як інсульт або інфаркт отримує рекомендації щодо зниження ризику, хоча оцінка факторів ризику розвитку серцево-судинних захворювань (наприклад за шкалою SCORE) і надання рекомендацій щодо їх зниження не потребує багато часу і досить ефективно привертає увагу пацієнта. Такий низький відсоток пацієнтів можна пояснити недостатнім сприйняттям інформації під час спілкування з лікарем, пізнім зверненням по допомогу або нечіткими інструкціями лікаря. Особливо це стосується пацієнтів з візуальним сприйняттям інформації [26]. Крім 
ПРОФИЛАКТИКА ХРОНИЧЕСКИХ

НЕИНФЕКЦИОННЫХ ЗАБОЛЕВАНИЙ

В УСЛОВИЯХ ПАНДЕМИИ COVID-19

Елизарова Е.Т., Гозак С.В., Полька Н.С., Парац А.Н., Станкевич Т.В.

ДУ «Институт общественного здоровья

им. Марзеева НАМН Украины», Г. Киев

Повсеместная распространенность хронических неинфекционных заболеваний (НИЗ), являющихся доминирующей причиной смертности и инвалидности, обусловливает необходимость научных исследований с целью разработки путей профилактики и улучшения методик ранней диагностики. В настоящее время актуальность профилактики НИЗ

приобретает особое значение, поскольку пациенты с НИЗ относятся к группе риска с тяжелым течением COVID-19. Учитывая особенности урбанизации, изучение эпидемиологии факторов риска НИЗ необходимо проводить для городского и сельского населения отдельно.

Цель исследования: систематизация факторов риска развития хронических неинфекционных заболеваний городского населения Украины.

Материалы и методы. Проведен контекстный поиск с последующими аналитическими выводами в базах данных государственных учреждений Украины, the World Health Data Platform, the Global Burden of Disease IHME, Pub Med, Cochrane Library.
Результаты. Демографические тенденции в Украине характеризуются преобладанием смертности над рождаемостью, с 1990 года численность населения сократилась на 19,2\%. НИЗ - основная причина смертности украинцев. Факторы риска НИЗ широко распространены среди населения Украины. Рост смертности связан с действием факторов риска, поздним выявлением НИЗ. Более половины населения старше 18 лет страдают избыточным весом и ожирением. В крупных городах за последние пять лет увеличилась доля людей с ожирением. Гиподинамия и неправильное питание также характерны для городских жителей. Дополнительным фактором риска НИЗ является загрязнение воздуха.

Выводы. Для городского населения Украины характерны такие факторы риска НИЗ, как старение населения, гипокинезия, нерациональное питание, загрязнение атмосферного воздуха, а также гиподиагностика НИЗ. Все эти факторы в сочетании с низким социально-экономическим уровнем большинства населения страны обусловливают необходимость более активного внедрения профилактических мероприятий.

\section{Ключевые слова: факторы риска, неинфекционные хронические заболевания, загрязнение атмосферного воздуха, смертность, COVID-19.}

цього, обізнаність щодо факторів ризику та практичне застосування знань часто не корелюють між собою. Так, у дослідженні [27] показано, що більша частина студентів $(80,9 \%)$ знає, що низька фізична активність є фактором ризику розвитку НІЗ, але тільки 55\% з них ведуть активний спосіб життя.

Необхідність підвищення знань і населення, і лікарів щодо профілактики таких НІЗ, як бронхіальна астма та новоутворення зумовлена високим рівнем виявлення цих захворювань у періоді тяжкого перебігу [28-29]. Зауважимо, що обидва захворювання належать до НІЗ, які суттєво підвищують ризик смерті, у тому числі й від COVID-19. Щодо бронхіальної астми, то причиною гіподіагностики є поліморфність проявів захворювання, особливо у дітей, тому одним з напрям- ків вирішення проблеми має бути підвищення кваліфікації лікарів. Інша ситуація склалася з новоутвореннями. Часто затримка діагностики пов'язана $з$ пізнім зверненням пацієнта через страх, сором або негативне сприйняття процедури. Наприклад, в опитуванні STEP щодо скринінгу на рак шийки матки 46,9\% жінок, які не проходили тест, повідомили про такі причини: $48,7 \%$ не мали інформації щодо місця і способу проходження тесту; 7,8\% відчували сором перед візитом до гінеколога; 26,5\% не мали часу зробити тест; для 7,8\% клініка була територіально віддаленою від місця проживання; 9,2\% назвали причиною страх [2]. Отже, необхідно підвищувати поінформованість населення про причини виникнення i можливість лікування онкологічних захворювань, а також про можливість профілактики розвитку новоутворень.

Окрім способу життя та метаболічних розладів, за даними the Global Burden of Disease, в українських містах значущим фактором ризику розвитку НІЗ та підвищення рівня смертності $€$ забруднення атмосферного повітря [6]. Результати наукових досліджень впливу забруднення атмосферного повітря на здоров'я міського населення України свідчать про небезпеку полютантів не тільки для розвитку серцевосудинних, легеневих та онкологічних захворювань у сучасного населення України, а й акцентують увагу на генотоксичній дії, що призводить до збільшення рівня новоутворень і підвищує ризик розвитку вроджених аномалій та НIЗ у майбутніх поколінь [30-34]. Дослідження ступеня забруднення атмосферного

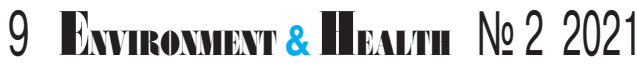


повітря твердими частками, тяжкості перебігу COVID-19 і напруженості епідемічної ситуації проводилось у Китаї, Італії, США та Нідерландах [35]. Дослідження показали асоціацію між цими показниками, що зумовлює необхідність продовження пошуку у цьому напрямку з визначенням причинно-наслідкових зв'язків.

Від 1998 року у країні функціонує система державного моніторингу якості атмосферного повітря згідно 3 Постановою Кабінету Міністрів України № 391 від 30.03.1998 р. № 391 «Про затвердження Положення про державну систему моніторингу довкілля», але ця система потребує розвитку та осучаснення. За даними Міністерства захисту довкілля та природних ресурсів, нині у країні впроваджується загальнодержавна система атмосферного моніторингу, яка б відповідала європейським вимогам і давала змогу порівняти показники забруднення повітря у регіонах України та в інших країнах. 2019 року було прийнято Постанову Кабінету Міністрів України № 827 «Деякі питання здійснення державного моніторингу у галузі охорони атмосферного повітря», яка регламентує зони моніторингу атмосферного повітря, кількість постів та перелік речовин з урахуванням вимог, що викладені у директивах Європейського Парламенту 2004/107€С та 2008/ 50/ЄС. Згідно з цією Постановою до переліку забруднюючих повітря речовин належить і визначення концентрацій твердих часток $\mathrm{PM}_{2.5}$, та $\mathrm{PM}_{10}$, які $€$ індикаторами ризику здоров'я [36].

Забруднювач $\mathrm{PM}_{2.5}$, другий після паління чинник ризику розвитку серцево-судинних, дихальних захворювань, також охарактеризований як канцерогенний фактор [3, 36]. Встановлено, що рівень забруднення повітря $\mathrm{PM}_{2.5}$, близько $20 \mu \mathrm{g} / \mathrm{m}^{3}$ на 16,8\% підвищує ризик розвитку інфекцій нижніх дихальних шляхів, на 22,9\% - хронічних обструктивних хвороб легень, на 45,0\% - розвиток діабету 2 типу, на 23,3-58,4\% - ішемічної хвороби серця, на 23,0-84,3\% - інсульту залежно від вікової групи [6]. Зауважимо, що забруднення повітря $\mathrm{PM}_{2.5}$ спричиняє триваліші наслідки для здоров'я, ніж $\mathrm{PM}_{10}$ за їхньої короткої дії [36]. Тривала дія $\mathrm{PM}_{2.5}$ підвищує ризик смерті від серцеволегеневих захворювань на 6$13 \%$, а $\mathrm{PM}_{10}$ - на 0,2-0,6\% за підвищеної концентрації на $10 \mu \mathrm{g} / \mathrm{m}^{3}$. Тому $\mathrm{PM}_{2.5}$ є одним зі значущих індикаторів, які наразі міжнародні експерти використовують для оцінки ризику здоров'я. Висунута гіпотеза щодо зв'язку між збільшенням кількості хворих і тяжкістю перебігу внаслідок COVID-19 [35] також вказує на необхідність фіксації цього показника. За даними ВООЗ, середня концентрація $\mathrm{PM}_{2.5}$ В українських містах становила 19,4 $\mu \mathrm{g} / \mathrm{m}^{3}$ (ДІ 12,17-37,33), a у сільській місцевості - 16,68 $\mu \mathrm{g} / \mathrm{m}^{3}$ (ДІ 11,25-27,95) [https: //bit.ly/31KBjOl]. Ці дані отримано у результаті вимірювань концентрації $\mathrm{PM}_{2.5}$ станціями громадського моніторингу, отже потребують уточнення [37]. Оскільки транспорт $€$ однією з причин високої концентрації $\mathrm{PM}_{2.5}$ у містах України [38], проблема законодавчого врегулювання проблеми автотранспорту є однією з нагальних.

Забруднення повітря у внутрішніх приміщеннях житлових та громадських будівель $€$ не менш значущим чинником ризику розвитку НІЗ і погіршення епідеміологічних та епідемічних показників [39]. Тому поширення інформації серед населення щодо необхідності дотримання гігієнічних умов у внутрішніх приміщеннях будівель $€$ також актуальним завданням, яке необхідно впроваджувати на всіх рівнях від індивідуального до державного.

Зауважимо, що забруднення повітря не тільки підвищує ризик розвитку НІЗ та смертності від них, але й знижує ймовірність рухової активності або нівелює її корисний вплив.

Серед проектів на майбутнє з покращання стану довкілля пропонуються проекти забудови міст, що засновані на таких елементах, як сонячна енергія та озеленення території, біонічні промислові та житлові будівлі, відсутність відходів, нульовий викид вуглекислого газу [37-38]. Вочевидь такі глобальні впровадження - це питання не сьогодення. Однак, враховуючи негативний вплив міського середовища на здоров'я сучасного населення та наступних поколінь, такі нагальні проблеми, як забруднення повітря та утилізація відходів промисловості необхідно вирішити вже зараз.

Отже, до факторів ризику, які нині загрожують здоров'ю української міської популяції, можна віднести поведінкові, метаболічні та екологічні чинники, а також низьку обізнаність населення щодо власного здоров'я. Зниження рухової активності міських жителів на тлі високого рівня захворювань, що входять у п'ятірку найбільш небезпечних неінфекційних захворювань, та пандемії COVID-19 є додатковим фактором ризику смертності та захворюваності населення. Через епідемічну ситуацію постає необхідність посилення уваги до профілактичних заходів попередження розвитку НІЗ та оздоровлення довкілля.

\section{Висновки}

Для міського населення України характерними $є$ такі чинники ризику НІЗ, як старіння населення, гіпокінезія, нераціональне харчування, забруднення атмосферного повітря, гіподіагностика НІЗ, низька обізнаність населення щодо власного здоров'я, а також погіршення епідемічної ситуації. Ці фактори у поєднанні з низьким соціально-економічним рівнем більшості населення країни формують необхідність більш 
активного впровадження профілактичних заходів.

ЛІТЕРАТУРА

1. The impact of the

COVID-19 pandemic on

noncommunicable disease

resources and services:

results of a rapid

assessment. Copenhagen :

WHO, 2020. 32 p. URL:

https://bit.ly/3ctMMle

2. STEPS survey reveals high prevalence of noncommunicable disease risk factors in Ukraine. Copenhagen : World Health Organization, 2020. 14 p.

3. Political declaration of the third high-level meeting of the General Assembly on the prevention and control of noncommunicable diseases. Time to deliver: accelerating our response to address noncommunicable diseases for the health and well-being of present and future generations. New York : United Nations, 2018. 7 p.

4. Jeong I.K., Yoon K.H., Lee M.K. Diabetes and COVID19: Global and regional perspectives. Diabetes Res Clin Pract. 2020. Vol. 166. P. 108-303. doi: $10.1016 /$ j.diabres.2020.108303.

5. Nishiga M., Wang D.W., Han Y., Lewis D.B., Wu J.C. COVID-19 and cardiovascular disease: from basic mechanisms to clinical perspectives. Nat Rev Cardiol. 2020. Vol. 17 (9). P. 543-558. doi: 10.1038/s41569-020-0413-9.

6. GBD 2019 Risk Factors Collaborators. Global burden of 87 risk factors in 204 countries and territories, 1990-2019: a systematic analysis for the Global Burden of Disease Study 2019. Lancet. 2020. Vol. 17. P. 1223-1249. doi: 10.1016/S01406736(20)30752-2.

7. Shawar Y.R., Crane L.G. Generating global political priority for urban health: the role of the urban health epistemic community. Health Policy Plan. 2017. Vol. 32 (8). P. 1161-1173. doi: 10.1093/heapol/czx065.
8. Vollset S.E., Goren E., Yuan C.W. et al. Fertility, mortality, migration, and population scenarios for 195 countries and territories from 2017 to 2100: a forecasting analysis for the Global Burden of Disease Study. Lancet. 2020. Vol. 17. P. 1285-1306. doi: 10.1016/S01406736(20)30677-2.

9. Schüz J., Espina C., Wild C.P. Primary prevention: a need for concerted action. Mol Oncol. 2019. Vol. 13 (3). P. 567-578. doi: 10.1002/1878-0261.12432.

10. Wild C.P., Espina C., Bauld L. et al. Cancer Prevention Europe. Mol Oncol. 2019. Vol. 13 (3). P. 528-534. doi: 10.1002/18780261.12455.

11. Piepoli M.F., Hoes A.W., Agewall S. Et al. ESCS cientific Document Group. 2016 European Guidelines on cardiovascular disease prevention in clinical practice: The Sixth Joint Task Force of the

European Society of Cardiology and Other Societies on Cardiovascular Disease Prevention in Clinical Practice (constituted by representatives of 10 societies and by invited experts) Developed with the special contribution of the European Association for Cardiovascular Prevention \& Rehabilitation (EACPR). Eur Heart J. 2016. Vol. 37 (29). P. 2315-2381. doi: 10.1093/eurheartj/ehw106.

12. Winnige P., Vysoky R., Dosbaba F., Batalik L. Cardiac rehabilitation and its essential role in the secondary prevention of cardiovascular diseases. World J Clin Cases. 2021. Vol. 16. P. 1761-1784. doi: 10.12998/wjcc.v9.i8.1761. 13. Paliychuk O.V.,

Polishchuk L.Z., Rossokha Z.I., Chekhun V.F. Molecular-genetic models for prognosis of development of tumors of reproductive system in women with family history of cancer.

Exp Oncol. 2018. Vol. 40 (1). P. 59-67.

14. Malik V.S., Willet W.C., Hu F.B. Nearly a decadeon - trends, risk factors and policy implications in global obesity. Nat Rev Endocrinol. 2020.

Vol. 16. P. 615-616.

https://doi.org/10.1038/s4157 4-020-00411-y

15. Liu J., Ren ZH., Qiang $\mathrm{H}$. et al. Trends in the incidence of diabetes mellitus: results from the Global Burden of Disease Study 2017 and implications for diabetes mellitus prevention. BMC Public Health. 2020. Vol. 20. P. 1415. https://doi.org/10.1186/s1288 9-020-09502-x

16. Myers J., Kokkinos P., Nyelin E. Physical Activity, Cardiorespiratory Fitness, and the Metabolic Syndrome. Nutrients. 2019. Vol. 11 (7) P. 1652. doi: 10.3390/nu11071652.

17. Yu E., Malik V.S., Hu F.B. Cardiovascular Disease

Prevention by Diet

Modification: JACC Health

Promotion Series. J Am Coll

Cardiol. 2018. Vol. 72 (8).

P. 914-926. doi:

10.1016/j.jacc.2018.02.085.

18. Polka N.S., Dobrianska O.V., Turos O.I., Dardynskaia I.V., Zeingler D. The Peculiarities of the Prevalence of Tobacco Smoking among Schoolchildren in Ukraine. Childshealth. 2016. Vol. 6. P. 27-30.

19. Yelizarova O., Stankevych T., ParatsA., Antomonov M., Polka N., Hozak S. Specific Features of the Ukrainian Urban Adolescents' Physical Activity: a CrossSectional Study. J Environ Public Health. 2020. e3404285. doi: 10.1155/2020/3404285.

20. Andrieieva O., Hakman A. Health status and morbidity of children 11-14 years of age during school. Journal of Physical Education and Sport. 2018. Supp. issue 2.

P. 1231-1236.

21. Соціально-демографічні характеристики домогосподарств в Україні.

Статистичний збірник / Державна служба статистики України. Київ, 2020. URL : https://bit.ly/2QNH1gh 
http://www.ukrstat.gov.ua/dru k/publicat/kat_u/2019/zb/07/z b_sdhdu2019.pdf

22. Islam S., Tabassum R., Liu Y. et al. The role of social media in preventing and managing non-communicable diseases in low-and-middle income countries: Hope or hype? Health Policy and Technology. 2019. Vol. 8, Issue 1. P. 96-101. https://doi.org/10.1016/j.hlpt. 2019.01.001.

23. Hussain A., Mahawar K., Xia Z., Yang W., El-Hasani S. Obesity and mortality of COVID-19. Meta-analysis. Obes Res Clin Pract. 2020. Vol. 14 (4). P. 295-300. doi: 10.1016/j.orcp.2020.07.002.

24. Zhong R., Chen L., Zhang Q. et al. Which Factors, Smoking, Drinking Alcohol, Betel Quid Chewing, or Underlying Diseases, are More Likely to Influence the Severity of COVID-19? Front Physiol. 2021. Vol. 11. e623498. doi: 10.3389/fphys.2020.623498.

25. Рингач Н.О. Грамотність з питань здоров'я і досягнення Цілей сталого розвитку в Україні. Демографія та соціальна економіка. 2020. Vol. 2 (40). P. 71-88. https://doi.org/10.15407/dse2 020.02.071

26. Катеренчук І.П., Мохначов О.В. Комплаєнс як передумова ефективності терапії коморбідного перебігу гіпертонічної хвороби. Вісник проблем біології $i$ медицини. 2019. Вип. 2, т. 2. С. $120-123$.

27. Сердюк А.М., Гуліч М.П., Коблянська А.В., Любарська Л.С., Петренко О.Д., Харченко О.О., Ященко О.В., Ольшевська О.Д.

Обґрунтування наукових засад реалізації заходів профілактики неінфекційних захворювань в Україні відповідно до цілей сталого розвитку. Актуальні питання захисту довкілля та здоров'я населення України (результати наукових розробок 2018). К., 2019. Вип. 5. C. $18-100$.

28. Бронхіальна астма. Хронічне обструктивне захворювання легень. В світлі сучасних рекомендацій GINA (2017), SIGN 153 (2016), GOLD (2017), NICE (2010) / за ред. Фещенка Ю.І. К. : ТОВ «Доктор-Медіа-Груп», 2018. $220 \mathrm{c}$.

29. Ковальов О.О. Україна проти раку: національна програма онкологічного скринінгу. Онкологія, Гематологія, Хіміотерапія. 2019. № 3 (59). C. 8-9.

30. Турос О.І. Аналіз довгострокового спостереження за станом атмосферного повітря, який здійснюється органами санітарно-епідеміологічної служби України. Мед. перспективи. 2008.

№ 3. C. 52-56.

31. Serdyuk A.M., Hushchuk I.V., Chernychenko I.O., Lytvychenko O.M. Features of atmospheric air pollution in a non-industrial city: risk for the population. Medycni perspektyvy. 2019. T. 24. № 4. P. 154159. doi: 10.26641/23070404.2019.4.189609

32. Черниченко І.О., Литвиченко О.М., Соверткова Л.С., Цимбалюк С.М. Оцінка канцерогенного ризику для населення промислових міст України. Довкілля та здоров'я. 2017. № 2. Р. 17-22. https://doi.org/10.32402/dovk il2017.02.017

33. Турос О.І. Розробка наукових підходів до вдосконалення гігієнічної оцінки небезпеки від джерел забруднення атмосферного повітря на основі показників ризику: автореф. дис... д-ра мед. наук: 14.02.01. К., 2008. 39 c.

34. Турос О.І., Петросян А.А., Давиденко Г.М. Оцінка соціальних втрат здоров'я населення, зумовлених промисловим забрудненням атмосферного повітря викидами зважених часток (3410). Медичні перспективи. 2017. Т. 22, № 1. C. 97-102.

35. In'tVeen J.C.C.M., Kappen J.H., van Schayck O.C.P. Luchtverontreiniging: een determinant voor COVID-19? [Air pollution: a determinant for COVID-19?].
Ned Tijdschr Geneeskd. 2020. Vol. 164. eD5153. URL : https://www.ntvg.nl/system/fil es/publications/d5153.pdf

36 . Health risk assessment of air pollution: general principles. Copenhagen: WHO Regional Office for Europe, 2016. $40 \mathrm{p}$.

37. Turos O., Maremukha T. Petrosian A., Mykhina L., Morhulova V. Integral indicators as tools for air quality assessment. Довкілля та здоров'я. 2019. № 1 (90). C. 51-55. https://doi.org/10.32402/dovk il2019.01.051

38. Національна доповідь про стан навколишнього природного середовища в Україні у 2018 році / Міністерство захисту довкілля та природних ресурсів України. К., 2019. 483 с.

39. Brunekreef B., Downward G., Forastiere F. et al. Air pollution and COVID-19. Luxembourg : European Parliament, 2021. $66 \mathrm{p}$.

40. Krzemi ska A.E.,

Zareba A.D., Dzikowska A., Jarosz K.R. Cities of the futurebionic systems of new urban environment. Environ Sci Pollut Res Int. 2019. Vol. 26 (9).

P. 8362-8370. doi:

10.1007/s11356-017-0885-2. REFERENCES

1. The Impact of the COVID19 Pandemic on Noncommunicable Disease Resources and Services:

Results of a Rapid Assessment. Copenhagen : WHO ; 2020 : 32 p. URL : https://www. who.int/publications/i/item/ncds-covid-rapidassessment.

2. STEPS Survey Reveals High Prevalence of Noncommunicable Disease Risk Factors in Ukraine. Copenhagen : World Health Organization; 2020 : 14 p.

3. Political Declaration of the Third High-Level Meeting of the General Assembly on the Prevention and Control of Noncommunicable Diseases. Time to Deliver: Accelerating our Response to Address Noncommunicable Diseases for the Health and Well-Being of Present and Future 
Generations. New York : United Nations ; $2018: 7 \mathrm{p}$.

4. Jeong I.K., Yoon K.H. and Lee M.K. Diabetes and COVID19: Global and Regional Perspectives. Diabetes Res ClinPract. 2020 ; 166 : 108303. doi: $10.1016 / \mathrm{j}$.diabres.2020.108303.

5. Nishiga M., Wang D.W., Han Y., Lewis D.B. and Wu J.C. COVID-19 and Cardiovascular Disease: from Basic Mechanisms to Clinical Perspectives. Nat Rev Cardiol. 2020 ; 17 (9) : 543-558. doi: 10.1038/s41569-020-0413-9.

6. GBD 2019. Risk Factors Collaborators. Global Burden of 87 Risk Factors in 204 Countries and Territories, 1990-2019: a Systematic Analysis for the Global Burden of Disease Study 2019. Lancet. 2020 ; 17 : 1223-1249. doi:

10.1016/S0140-

6736(20)30752-2.

7. Shawar Y.R. and

Crane L.G. Generating Global Political Priority for Urban Health: the Role of the Urban Health Epistemic Community. Health Policy Plan. 2017 ; 32

(8) : 1161-1173. doi:

10.1093/heapol/czx065.

8. Vollset S.E., Goren E., Yuan C.W. et al. Fertility, Mortality, Migration and Population Scenarios for 195 Countries and Territories from 2017 to 2100: a Forecasting Analysis for the Global Burden of Disease Study. Lancet. 2020 ; 17 : 1285-1306. doi: $10.1016 / S 0140-$ 6736(20)30677-2.

9. Schüz J., Espina C. and Wild C.P. Primary Prevention: a Need for Concerted Action. Mol Oncol. 2019 ; 13 (3) : 567578. doi: $10.1002 / 1878-$ 0261.12432.

10. Wild C.P., Espina C., Bauld L. et al. Cancer Prevention Europe. Mol Oncol. 2019 ; 13 (3) : 528-534. doi: 10.1002/1878-0261.12455.

11. Piepoli M.F., Hoes A.W., Agewall S. et al. ESCS Scientific Document Group. 2016 European Guidelines on Cardiovascular Disease Prevention in Clinical Practice: The Sixth Joint Task Force of the European Society of Cardiology and Other Societies on Cardiovascular Disease

Prevention in Clinical

Practice (Constituted by

Representatives of 10

Societies and by Invited

Experts) Developed with the

Special Contribution of the

European Association for

Cardiovascular Prevention \&

Rehabilitation (EACPR). Eur

Heart J. 2016 ; 37 (29) :

2315-2381. doi: 10.1093/eurheartj/ehw106.

12. Winnige P., Vysoky R.

Dosbaba F. and Batalik L.

Cardiac Rehabilitation and its

Essential Role in the

Secondary Prevention of

Cardiovascular Diseases.

World J Clin Cases. 2021 ; 16 :

1761-1784. doi:

10.12998/wjcc.v9.i8.1761.

13. Paliychuk O.V.,

Polishchuk L.Z., Rossokha Z.I. and Chekhun V.F. MolecularGenetic Models for Prognosis of Development of Tumors of Reproductive System in Women with Family History of Cancer. Exp Oncol. 2018 ; 40 (1) : 59-67.

14. Malik V.S., Willet W.C. and Hu F.B. Nearly a Decadeon - Trends, Risk Factors and Policy Implications in Global Obesity. Nat Rev Endocrinol. $2020 ; 16: 615-616$.

https://doi.org/10.1038/s4157 4-020-00411-y

15. Liu J., Ren ZH., Qiang H. et al. Trends in the Incidence of Diabetes Mellitus: Results from the Global Burden of Disease Study 2017 and Implications for Diabetes Mellitus

Prevention. BMC Public

Health. 2020 ; 20 :

1415.https://doi.org/10.1186/ s12889-020-09502-x STEP

16. Myers J., Kokkinos P. and Nyelin E. Physical Activity, Cardiorespiratory Fitness, and the Metabolic Syndrome. Nutrients. 2019 ; 11 (7) : 1652. doi:

10.3390/nu11071652.

17. Yu E., Malik V.S. and

Hu F.B. Cardiovascular Disease Prevention by Diet

Modification: JACC Health

Promotion Series.

J Am Coll Cardiol. 2018 ;
72 (8) : 914-926. doi:

10.1016/j.jacc.2018.02.085.

18. Polka N. S., Dobrian-

ska O.V., Turos O.I., Dardynskaia I.V. and Zeingler D. The Peculiarities of the Prevalence of Tobacco Smoking among Schoolchildren in Ukraine. Childshealth. 2016 ; 6 : 27-30.

19. Yelizarova O., Stankevych T., Parats A., Antomonov M., Polka N. and Hozak S. Specific Features of the Ukrainian Urban Adolescents' Physical Activity: a CrossSectional Study. J Environ Public Health. 2020 : e3404285. doi: $10.1155 / 2020 / 3404285$

20. Andrieieva O. and Hakman A. Health Status and Morbidity of Children 11-14 Years of Age During School. Journal of Physical Education and Sport. 2018 ; 2 : 1231-1236.

21. State Statistics Service of Ukraine. Sotsialno-demohrafichni kharakterystyky domohospodarstv Ukrainy u 2019 rotsi [Social and Demographic Characteristics of Households of Ukraine]. Kyiv ; 2020. URL : : https://bit.ly/2QNH1gh http://www.ukrstat.gov.ua/dru k/publicat/kat_u/2019/zb/07/z b_sdhdu2019.pdf

(in Ukrainian).

22. Islam S., Tabassum R., Liu Y. et al. The Role of Social Mediain Preventing and Managing Non-Communicable Diseases in Low-and-Middle Income Countries: Hope or Hype? Health Policy and Technology. 2019; 8 (1) : 96-101. https://doi.org/10.1016/j.hlpt. 2019.01.001.

23. Hussain A., Mahawar K., Xia Z., Yang W., El-Hasani S. Obesity and Mortality of COVID-19. Meta-Analysis. Obes Res Clin Pract. 2020 ; 14 (4) : 295-300. doi: 10.1016/j.orcp.2020.07.002. 24. Zhong R., Chen L., Zhang Q. et al. Which Factors, Smoking, Drinking Alcohol, Betel Quid Chewing, or Underlying Diseases, are More Likely to Influence the Severity of COVID-19? Front Physiol. 2021 ; 11 : e623498. doi: 
10.3389/fphys.2020.623498

25. Rynhach N.O. Hramotnist z pytan zdorovia i dosiahnennia Tsilei staloho rozvytku v Ukraini [Health Literacy and Achievement of Sustainable Development Goals in Ukraine]. Demography and Social Economy. 2020 ; 2 (40) : 71-88.

https://doi.org/10.15407/dse2 020.02.071 (in Ukrainian).

26. Katerenchuk I.P. and Mokhnachov O.V. Komplaiens yak peredumova efektyvnosti terapii komorbidnoho perebihu hipertonichnoi khvoroby [Compliance as a Prerequisite for the Effectiveness of Comorbid HypertensionTreatment]. Visnyk problem biolohii $i$ medytsyny. 2019 ; 2 (2) : 120123 (inUkrainian).

27. Serdiuk A.M., Hulich M.P., Koblianska A.V., Liubarska L.S., Petrenko O.D., Kharchenko O.O., Yashchenko O.V. and Olshevska O.D. Obgruntuvannia naukovykh zasad realizatsii zakhodiv profilaktyky neinfektsiinykh zakhvoriuvan v Ukraini vidpovidno do tsilei staloho rozvytku [Substantiation of the Scientific Bases of the Realization of Measures for Prevention of NonCommunicable Diseases in Ukraine According to the Objectives of Sustainable Development]. In : Aktualni pytannia zakhystu dovkillia ta zdorovia naselennia Ukrainy (rezultaty naukovykh rozrobok 2018) [Current Issues of Environmental Protection and Health of the Population of Ukraine (Results of Scientific Developments, 2018)]. Kyiv ; 2019 ; 5 : 18-100 (in Ukrainian).

28. Feshchenko Yu.I. (ed.). Bronkhialna astma. Khronichne obstruktyvne zakhvoriuvannia lehen. V svitli suchasnykh rekomendatsii GINA (2017), SIGN 153 (2016), GOLD (2017), NICE (2010) [Bronchial Asthma. Chronic Obstructive Pulmonary Disease. In the Light of the Current Recommendations of the GINA (2017), SIGN 153 (2016),
GOLD (2017), NICE

(2010)]. Kyiv ; 2018 : 220 p.

(in Ukrainian).

29. Kovalov O.O. Ukraina proty raku: natsionalna prohrama onkolohichnoho skryninhu [Ukraine Against Cancer: National Cancer Screening Program]. Onkolohiia, Hematolohiia, Khimioterapiia. 2019 ; 3 (59) : 8-9 (in

Ukrainian).

30. Turos O.I. Analiz

dovhostrokovoho

sposterezhennia za stanom atmosfernoho povitria, yakyi zdiisniuietsia orhanamy sanitarno-epidemiolohichnoi sluzhby Ukrainy [Analysis of Long-Term Monitoring of Ambient Air which Is Carried out by the Sanitary-

Epidemiological Service of Ukraine]. Medychni perspektyvy. 2008 ; 3 : 52-56

(in Ukrainian).

31. Serdyuk A.M., Hushchuk I.V., Chernychenko I.O. and Lytvychenko O.M. Features of Atmospheric Air Pollution in a Non-Industrial City: Risk for the Population. Medical

Perspectives. 2019 ; 24 (4) : 154-159. doi: 10.26641/23070404.2019.4.189609

32. Chernychenko I.O., Lytvychenko O.M., Sovertkova L.S. and Tsymbaliuk S.M. Otsinka kantserohennoho ryzyku dlia naselennia promyslovykh mist Ukrainy [Carcinogenic Risk

Assessment for the Population of Industrial Cities of Ukraine]. Dovkillia ta zdorovia

(Environment \& Health). 2017 ; $2: 17-22$.

https://doi.org/10.32402/dovk il2017.02.017 (in Ukrainian).

33. Turos O.I. Rozrobka naukovykh pidkhodiv do vdoskonalennia hihiienichnoi otsinky nebezpeky vid dzherel zabrudnennia atmosfernoho povitria na osnovi pokaznykiv ryzyku: avtoref. dys... doktora med. nauk [Development of the Scientific Approaches to the Improvement of the Hygienic Assessment of the Hazards from the Sources of Atmospheric Pollution on the Basis of Risk Indicators: Summary Dis. Dr. Med. Sci.].
Kyiv ; 2008 : 39 p.

(in Ukrainian).

34. Turos O.I., Petrosian A.A. and Davydenko H.M. Otsinka sotsialnykh vtrat zdorovia naselennia, zumovlenykh promyslovym zabrudnenniam atmosfernoho povitria vykydamy zvazhenykh chastok (ZCh10) [Assessment of the Social Losses of the Health of the Population Caused by Industrial Atmospheric Pollution with Suspended Particules' Emissions $\left.\left(\mathrm{P}_{10}\right)\right]$. Medical Perspectives. 2017 ; 22 (1) : 97 102 (in Ukrainian).

35. In 'tVeen J.C.C.M., Kappen J.H. and van Schayck O.C.P. Luchtverontreiniging: een determinant voor COVID19? [Air Pollution: a Determinant for COVID-19?]. Ned Tijdschr Geneeskd. 2020 ; 164 : eD5153. URL :

https://www.ntvg.nl/system/fil es/publications/d5153.pdf

36. Health Risk Assessment of Air Pollution: General Principles. Copenhagen: WHO Regional Office for Europe ; 2016 : $40 \mathrm{p}$

37. Turos O., Maremukha T., Petrosian A., Mykhina L. and Morhulova V. Integral Indicators as Tools for Air Quality Assessment. Dovkillia ta zdorovia (Environment \& Health). $2019 ; 1$ (90) : 51-55. https://doi.org/10.32402/dovk il2019.01.051

38. Natsionalna dopovid pro stan navkolyshnoho pryrodnoho seredovyshcha $v$ Ukraini u 2018 rotsi [National Report on the State of the Environment in Ukraine in 2018]. Ministry of Ecology and Natural

Resources of Ukraine. Kyiv ; 2019 : 483 p. (in Ukrainian).

39. Brunekreef B., Downward G., Forastiere F. et al. Air Pollution and COVID-19. Luxembourg : European Parliament ; 2021 : $66 \mathrm{p}$.

40. Krzeminska A.E., Zareba A.D., Dzikowska A. and Jarosz K.R. Cities of the Future-Bionic Systems of New Urban Environment. Environ Sci Pollut Res Int. 2019 ; 26 (9) : 8362-8370. doi:

10.1007/s11356-017-0885-2.

Надійшло до редакції 18.01.21 